\title{
PENGARUH MODEL PEMBELAJARAN TARI KREATIF TERHADAP KEMAMPUAN MOTORIK KASAR KELOMPOK B GUGUS I KECAMATAN BANJAR
}

\author{
Luh Putu Lestariani ${ }^{1}$, Luh Putu Putrini Mahadewi ${ }^{2}$,Putu Aditya Antara ${ }^{3}$ \\ 1,3 Jurusan Pendidikan Dasar, ${ }^{2}$ Jurusan IPPBK \\ Universitas Pendidikan Ganesha \\ Singaraja, Indonesia \\ e-mail:putu.lestariani@undiksha.ac.id,.Ipp-mahadewi@undiksha.ac.id, \\ putu.aditya.antara@undiksha.ac.id
}

\begin{abstract}
Abstrak
Permasalahan dalam penelitian ini adalah kemampuan motorik kasar pada anak kelompok B di Gugus I Kecamatan Banjar,Kabupaten Buleleng Tahun Pelajaran 2018/2019. Penelitian ini bertujuan untuk mengetahui perbedaan hasil kemampuan motorik kasar antara kelompok yang dibelajarkan dengan model pembelajaran tari kreatif dengan kelompok anak yang dibelajarkan dengan model pembelajaran konvensional pada kelompok B di TK Gugus I kecamatan Banjar Tahun Pelajaran 2018/2019. Penelitian ini termasuk penelitian semu yang menggunakan desain non- equivalent posttest only control group design. Dengan teknik Cluster Sampling untuk mengambil sampel dari populasi. Sebanyak 26 orang anak kelompok B Taman KanakKanak Sinar Harapan dilibatkan sebagai kelompok eksperimen dan 25 orang anak kelompok B Taman Kanakkanak Widya Kumara Sari dilibatkan sebagai kelompok kontrol. Teknik pegumpulan data menggunakan teknik observasi, kemudian data yang terkumpul dianalisis dengan menggunakan uji-t. Hasil penelitian ini menemukan bahwa terdapat perbedaan hasil kemampuan motorik kasar antara kelompok anak yang dibelajarkan dengan model pembelajaran tari kreatif dengan kelompok anak yang dibelajarkan dengan model pembelajaran konvensional kelompok B. Hal ini ditunjukkan dengan hasil signifikan yaitu $5 \%$ dengan derajat kebebasan 49 maka, thitung >ttabel yaitu 24,13>2,009. Jadi H1 diterima dan H0 ditolak. Skor rata-rata siswa kelompok eksperimen yaitu 74,84 , dan skor rata-rata kelompok kontrol yaitu 45,16 . Hal ini berarti skor ratarata kelompok eksperimen>skor rata-rata kelompok kontrol. Hasil tersebut menunjukkan bahwa terdapat perbedaan antara kemampuan motorik kasar pada anak yang dibelajarkan dengan model pembelajaran tari kreatif dengan anak yang dibelajarkan dengan model pembelajaran konvensional pada anak kelompok B di TK Gugus I Kecamatan Banjar Tahun Pelajaran 2018/2019.
\end{abstract}

Kata-kata Kunci: kemampuan motorik kasar, tari kreatif.

\begin{abstract}
The problem in this study was gross motor skills in children group B in group I Kecamatan Banjar,Kabupaten Buleleng of the study year 2018/2019. This study aimed at determining the differences of the results of gross motor skill between groups who were taught with creative dance learning model with groups of children who were taught with conventional learning model in group B at TK Gugus I Kecamatan Banjar in academic year 2018/2019. This research was a quasi-research using non-equivalent post-test only control group design. This study used Cluster Sampling technique to take samples from the population. There were 26 children in group B of Taman Kanak-Kanak Sinar Harapan which were involved as the experimental group and 25 children in group B of Taman Kanak-Kanak Widya Kumara Sari as the control group. The data collection techniques used observation techniques, then the data collected were analyzed using t-test. The results of this study found that there were differences in the results of gross motor skill between groups of children who were taught by creative dance learning model with groups of children who were taught by conventional learning model in group $B$. The results were indicated by significant results, that was, $5 \%$ with 49 degrees of freedom, tcount> ttable which was $24,13>2,009$. $\mathrm{H} 1$ was accepted and $\mathrm{H} 0$ was rejected. The average score of the experimental
\end{abstract}


group was 74.84 , and the average score of the control group was 45.16 . It means that the average score of the experimental group $>$ the average score of the control group. The results indicate that there is a difference between gross motor skill of children who were taught by creative dance learning model with children who were taught with conventional learning model in group B in TK Gugus I Kecamatan Banjar in academic year 2018/2019.

Keywords: rude motor ability, creative dance

\section{PENDAHULUAN}

Anak usia dini berada pada masa pertumbuhan dan perkembangan yang sangat pesat. Sehingga pada masa tersebut anak akan mengalami perubahan- perubahan baik secara jasmani maupun rohani. Perkembangan merupakan suatu proses perubahan kearah yang lebih baik yaitu bertambahnya kualitas atau kuantitas sesuatu. Perkembangan bersifat kumulatif yang artinya perkembangan yang terdahulu merupakan dasar bagi perkembangan yang selanjutnya. Perkembangan pada anak usia dini merupakan perkembangan yang dalam prosesnya memerlukan banyak stimulus karena anak usia dini berada dalam masa keemasan yaitu masa di mana anak dapat berkembang dengan sangat pesat maka penting bagi anak usia dini untuk dipenuhi kebutuhannya berupa kebutuhan fisik dan psikologis.

Kebutuhan anak usia dini salah satunya adalah kebutuhan atas pendidikan.Adapun tujuan pendidikan anak usia dini sebagaimana yang tertuang dalam Permendiknas No. 137 tahun 2014 Tentang Standar Pendidikan Anak Usia Dini bahwa: "Pendidikan anak usia dini bertujuan untuk membantu pertumbuhan dan perkembangan jasmani dan rohani agar anak memiliki kesiapan dalam memasuki pendidikan lebih lanjut"

Perkembangan anak usia dini dibagi menjadi beberapa aspek perkembangan. Mengacu pada Permendiknas No. 137 Tahun 2014 Tentang Standar Nasional Pendidikan Anak Usia Dini terdapat enam aspek perkembangan yaitu nilai agama dan moral, fisik motorik, kognitif, bahasa, sosial emosional, dan seni. Salah satu aspek yang sangat penting bagi anak usia dini adalah aspek perkembangan motorik.

Pendidikan dan Kebudayaan Republik Indonesia Nomor 137 Tahun 2014 tentang Standar Nasional Pendidikan Anak Usia Dini Bab IV Pasal 10 butir 3 ayat 1 menyatakan bahwa: Fisik motorik meliputi :a) motorik kasar, mencakup kemampuan gerakan tubuh secara terkoordinasi, lentur, seimbang, lincah, lokomontor, non-lokomotor, dan mengikuti aturan; b) motorik halus, mencakup kemampuan dan kelenturan menggunakan jari dan alat untuk mengeksplorasi dan mengekspresikan diri dalam berbagai bentuk; c) kesehatan dan perilaku, mencakup berat badan, tinggi badan, lingkar kepala sesuai usia serta kemampuan berperilaku hidup bersih, sehat, dan peduli terhadap keselamatanya.

Aspek perkembangan motorik kasar anak sangat penting untuk dikembangkan sejak dini. Samsudin, (2008: 9) mengatakan ,Pengayaan motorik kasar adalah kemampuan anak TK beraktivitas dengan menggunakan otot-otot besar. Kemampuan menggunakan otot-otot besar ini dilakukan untuk meningkatkan kualitas hidup anak TK kemampuan gerak dasar dibagi menjadi tiga kategori, yaitu; lokomotor, non-lokomotor, dan manipulatif.

Berdasarkan hasil pengamatan dii kelompok B Taman Kanak-kanak Gugus I Kecamatan Banjar Tahun Pelajaran 2018/2019 telah terjadi permasalahan perkembangan anak, kemampuan motorik anak usia 5-6 tahun seharusnya sudah mampu melakukan gerakan tubuh secara terkoordinasi untuk melatih kelenturan, keseimbangan dan kelincahan. Namun, masih banyak anak yang belum berkembang motoriknya terutama pada perkembangan motorik kasar. Motorik kasar anak belum berkembang secara optimal terlihat saat anak cenderung merasa bosan ketika ada kegiatan yang berhubungan dengan motorik kasar seperti saat senam irama dilakukan masih banyak anak-anak yang tidak mau menggerakkkan anggota tubuhnya anak hanya diam dan tidak mau memperhatikan guru didepannya. Apalagi saat ada kegiatan ekstrakulikuler tari bali anak-anak cenderung tertekan dan bahkan anak tidak mau lagi ikut kegiatan tari bali karena anak tidak diberikan kebebasan untuk bergerak.

Menunjukkan kegiatan proses pembelajaran yang masih kurang aktif dikarenakan penggunaan media dan kegiatan yang disediakan guru tidak menarik, teknik serta metode yang digunakan guru tidak tepat, sehingga anak merasa terpaksa dan cepat jenuh dalam menari. Akibatnya proses 
pembelajaran yang dilaksanakan oleh pendidik masih monoton dan berpusat pada guru (techer center) dalam pembelajaran mengembangkan motorik kasar anak karena hanya mengandalkan kegiatan-kegiatan yang sama. Dengan demikian perlu dilakukannya perbaikan dan inovasi baru untuk meningkatkan mutu pembelajaran yang berkualitas dan meningkatkan kualitas pendidikan dengan harapan mampu mengembangkan kemampuan motorik kasar.

Perkembangan motorik merupakan proses tumbuh kembang kemampuan gerak seorang anak. Setiap gerakan yang dilakukan anak merupakan hasil pola interaksi yang kompleks dari berbagai bagian dan sistem dalam tubuh yang dikontrol otak.

Berdasarkan hal tersebut, peneliti ingin mengembangkan kemampuan motorik kasar anak melalui sebuah tari kreatif/gerak kreatif. Tari kreatif /gerak kreatif (creative movement) digunakan sebagai cara mengekspresikan diri anak secara bebas sesuai dengan imajinasinya. Dengan mengekspresikan berbagai imajinasinya anak mampu mengembangkan berbagai potensi lainnya (Antara , 2015:113). Riadi dan Agus (2018:29) menyatakan, pembelajaran tari kreatif pada dasarnya berusaha untuk memperkuat dan memperlancar stimulus dan respons anak didik dalam pembelajaran,sehingga proses pembelajaran menjadi hal yang menyenangkan dan tidak membosankan.

Hawkins (2003: 12) (dalam Antara 2015:113) menyatakan, Kegiatan yang perlu dilakukan dalam pelaksanaan gerak kreatif yang dikaitkan dengan proses kreatif yaitu merasakan (menyerap), menghayati, menghayalkan, dan memberi bentuk. Berbagai komponen yang ada dalam gerak kreatif ini harus bisa dihubungkan dengan baik oleh pendidikan sehingga ketotalitasan dalam menampilkan gerak kreatif ini menjadi lebih sempurna dan mampu mengekspresikan diri anak.

Mencermati berbagai pendapat diatas, dapat disimpulkan bahwa gerak kreatif merupakan sebuah gerakan yang dilakukan secara bebas namun dapat memberikan makna dan arti tersendiri dan dapat memberi anak-anak banyak kesempatan untuk berimajinasi.

Tarian ini mencakup gerakan-gerakan tubuh yang dapat dilakukan anak, misalnya gerak kepala (tengadah, menoleh, memutar, dan menggeleng-gelengkan kepala), gerak badan (miring, membungkuk, goyang, dan memutar), gerak tangan (merentang, mengayun, mengangkat, bertepuk, dan sebagainya), gerak kaki (mengangkat, memutar, mengayun dan sebagainya). Berbagai minat perlu dilatih terutama melalui pembelajaran tari, karena pembelajaran tari dapat memberikan pengalaman belajar yang menyenangkan bagi anak serta akan terjadi perkembangan dari semua aspek pada diri anak termasuk aspek motorik kasar. Keterampilan motorik kasar merupakan keterampilan gerak tubuh secara harmonis yang berperan untuk mencapai keseimbangan yang menunjang gerak anak. Gerak sebagai media tari mengajarkan anak-anak untuk berimajinasi, berkreasi dan berekspresi. Menurut yulianti, (2016 : 31) menyatakan, Tari adalah kesenian yang terkait langsung dengan gerak tubuh manusia. Tubuh sebagai alat utama dan gerak tubuh merupakan media untuk mengekspresikan, menjadi satu kesatuan yang tidak dapat dipisahkan. Bahan-bahan gerak adalah jari-jari tangan, pergelangan tangan, kaki, tangan,kepala, mata dan sebagainya.

Untuk membuat kegiatan yang menyenangkan peneliti mencoba mengubah kegiatan Tari Tradisional yang sudah biasa diterapkan di TK B Gugus I Kecamatan Banjar menjadi tari kreatif yang lebih menarik. Untuk menciptakan sebuah tari kreatif perlu adanya stimulasi dari pendidik dan media pendukung lainnya. Oleh karena itu peneliti mencoba menggunakan model pembelajaran tari kreatif sebagai kegiatan baru yang dapat melatih kemampuan motorik kasar anak.

Melalui kegiatan tari kreatif ini anak akan lebih mudah untuk mempelajarinya dengan cara bergerak bebas sesuai imajinasinya dan irama musik yang sudah ditentukan oleh pendidik. Sehingga kegiatan tari kreatif ini membuat anak merasa senang, anak tidak merasa bosan dan tertekan. Dan tanpa disadari secara langsung otot-otot besar anak sudah terstimulasi dengan sendirinya. Anak merasa aktivitas yang mereka jalani merupakan sebuah hal yang baru dan kegiatan tidak monoton.

Adapun tujuan dari penelitian ini adalah untuk mengetahui perbedaan yang signifikan terhadap kemampuan motorik kasar antara kelompok anak yang dibelajarkan Model Pembelajaran Tari Kreatif dengan anak yang di belajarkan menggunakan Model Pembelajaran Konvensional pada Kelompok B Di Taman Kanak-kanak Gugus I Kecamatan Banjar Tahun Pelajaran 2018/2019.

Berdasarkan latar belakang masalah di atas maka peneliti menguji cobakan sebuah penelitian yang berjudul "Pengaruh Model Pembelajaran Tari Kreatif Terhadap Kemampuan Motorik Kasar Anak Kelompok B Di Taman Kanak-Kanak Gugus I Kecamatan Banjar Tahun Pelajaran 2018/2019". 


\section{METODE}

Jenis penelitian ini merupakan jenis penelitian eksperimen semu (quasi experiment). Penelitian eksperimen semu merupakan jenis penelitian yang mempunyai kelompok kontrol, tetapi tidak dapat berfungsi sepenuhnya untuk mengontrol variabel-variabel luar yang mempengaruhi pelaksanaan eksperimen (Sugiyono, 2011). Untuk melihat pengaruhnya dapat dilihat dengan cara membandingkan satu kelompok pembanding yang diberikan treatment yang berbeda. Agung,(2014: 163) Menyatakan rancangan eksperimen non-equivalent posttest only control group design, yang secara prosedural mengikuti pola seperti ditunjukkan pada table 0.1 .

Tabel 0.1.

Non-equivalent posttest only control group design

\begin{tabular}{ccc}
\hline Kelas & Treatment & Post-test \\
\hline Eksperimen & $\mathrm{X}$ & $\mathrm{O}_{1}$ \\
\hline Kontrol & - & $\mathrm{O}_{2}$
\end{tabular}

(Sumber: Agung, 2014:163)

Keterangan:

$\mathrm{O}_{1}=$ post-test terhadap kelompok eksperimen

$\mathrm{O}_{2}=$ post-test terhadap kelompok kontrol

$\mathrm{X}=$ treatment berupa model pembelajaran tari kreatif

- =kelompok kontrol (tidak mendapat perlakuan tetapi mendapat pembelajaran dengan model konvensional yang secara rutin dilakukan oleh guru)

Dari rancangan penelitian di atas dapat dijelaskan bahwa dalam penelitian terdapat kelas eksperimen dan kelas kontrol. Kemudian pada kelas eksperimen diberikan perlakuan atau treatmen berupa model pembelajaran tari kreatif(X1) sedangkan pada kelas kontrol tidak mendapat perlakuan atau treatmen (tetap menggunakan model pembelajaran konvensional yang sudah ada di sekolah). Pada akhir pertemuan di kelas eksperimen dan kelas kontrol akan sama-sama diberikan post-test (O1 dan O2).

Penelitian ini untuk dapat mengetahui variabel terikat dan variabel bebas. Variabel bebas yang digunakan dalam penelitian ini adalah model pembelajaran tari kreatif pada kelas eksperimen, sedangkan kelompok kontrol diberikan perlakuan dengan menggunakan model pembelajaran konvensional. Sedangkan Variabel terikat yang digunakan dalam penelitian ini adalah kemampuan motorik kasar pada anak kelompok B.

Dalam penelitian ini untuk menentukan subjek langkah awal dalam penelitian ini adalah menentukan populasi yang akan diteliti. Menurut Agung (2014:117) "Populasi adalah keseluruhan obyek dalam suatu penelitian" Sedangkan Menurut Sugiyono (2017:80) "Populasi adalah wilayah generalisasi yang terdiri atas, objek/subjek yang mempunyai kualitas dan karakteristik tertentu yang ditetapkan oleh peneliti untuk dipelajari dan kemudian ditarik kesimpulannya". Siswojo (dalam Sukardi, 2007:53) definisi dari populasi adalah: "semua anggota kelompok manusia, binatang, peristiwa, atau benda yang tinggal bersama dalam satu tempat dan secara terencana menjadi target kesimpulan dari hasil akhir suatu penelitian".

Berdasarkan pemaparan diatas dapat disimpulkan populasi adalah semua objek atau subjek yang memiliki karakteristik tertentu untuk ditarik kesimpulannya sebagai hasil akhir suatu penelitian. Adapun populasi dari penelitian ini adalah seluruh anak kelompok B di Taman Kanak-Kanak Gugus I Kecamatan Banjar yang berjumlah 326 orang.

Sampel penelitian adalah bagian dari populasi. Menurut Agung (2014:69) menyatakan bahwa "Sampel adalah sebagian dari populasi yang diambil yang dianggap mewakili seluruh populasi dan diambil dengan menggunakan teknik tertentu". Sependapat dengan hal tersebut, Koyan (2012:30) mengungkapkan bahwa "sampel merupakan bagian dari populasi". Menurut 
Sugiyono (2017:81) sampel adalah bagian dari jumlah dan karakteristik yang dimiliki oleh populasi tersebut.

Berdasarkan pemaparan diatas, dapat ditarik kesimpulan bahwa sampel merupakan bagian dari populasi yang dijadikan objek penelitian. Teknik yang digunakan mengambil sampel dari populasi menggunakan teknik Cluster Sampling. Menurut Setyosari (2016:224) teknik cluster digunakan apabila populasi atau sampel yang tersedia adalah berupa unit-unit rumpun dalam populasi. Penelitian eksperimental tentang pengaruh metode mengajar, biasanya menggunakan kelas atau kelompok, dan tidak mungkin mengambil secara acak setiap individual anak dari setiap kelas.

Menurut Sugiyono (2015:121) dalam penelitian ini teknik cluster sampling digunakan karena individu-individu pada populasi telah terdistribusi ke dalam kelas-kelas, sehingga tidak mungkin untuk melakukan pengacakan terhadap individu-individu dalam populasi. Teknik ini dilakukan dengan cara mula-mula seluruh kelompok kelas atau anggota populasi di tulis namanya pada kertas kecil yang berukuran $5 \times 5 \mathrm{~cm}$. Kemudian kertas-kertas yang ditulis nama tersebut digulung dan dimasukkan kedalam satu wadah. Kemudian dikocok kemudian diambil satu gulungan kertas,lalu ambil satu gulungan kertas lain tanpa memasukkan kembali gulungan kertas pertama. Nama-nama yang tercantum pada kedua gulungan kertas tersebut merupakan sampel penelitian, sehingga telah didapatkan dua kelompok kelas. Menurut Sugiyono (2015:121) dalam penelitian ini teknik cluster sampling digunakan karena individu-individu pada populasi telah terdistribusi ke dalam kelas-kelas, sehingga tidak mungkin untuk melakukan pengacakan terhadap individu-individu dalam populasi. Sampel dalam penelitian ini adalah Kelompok B Gugus I Kecamatan Banjar, sebagai kelompok kontrol TK Widya Kumara Sari yang terdiri dari 25 anak, dan TK Sinar Harapan sebagai kelompok eksperimen yang terdiri dari 26 anak.

Data yang ingin diketahui dalam penelitian ini adalah data tentang hasil pemberian tritment model pembelajaran tari kreatif terhadap kemampuan motorik kasar pada kelompok B di Taman Kanak-kanak Sinar Harapan tahun 2018/2019. Untuk itu pengumpulan data tersebut, dalam penelitian ini menggunakan metode observasi.

Observasi adalah cara yang dilakukan untuk mengamati semua tingkah laku yang terlihat pada suatu jangka waktu tertentu atau pada suatu tahap perkembangan tertentu. Bilamana peneliti melakukan semua pencatatan tanpa mengubah suasana atau mengontrol dalam situasi-situasi yang direncanakan, maka hal itu disebut dengan observasi alami (dalam Gunarsa, 2012:65). Martin ( dalam Agung,2014) menyatakan, observasi adalah "pengamatan dan pencatatan secara sistematis terhadap unsur-unsur yang tampak dalam suatu gejala atau gejala-gejala dalam objek penelitian.

Observasi dilakukan dengan, menggunakan indra pengeliatan dan indra pendukung antara lainnya, pendengar, pencium,pengecap dan lain-lainnya. Observasi juga dilakukan dengan menggunakan lembar observasi dalam bentuk ( checklist). Dengan katagori skor 1,2,3,4. Skor 1 untuk katagori tidak mampu, skor 2 untuk katagori mampu dengan bantuan guru, skor 3 untuk katagori mampu, dan skor 4 untuk katagori sangat mampu.

\section{HASIL DAN PEMBAHASAN}

Berdasarkan hasil temuan dapat dinyatakan kedua kelompok sampel penelitian yang memiliki kemampuan setara, setelah diberikan perlakuan berupa pembelajaran dengan menggunakan model pembelajaran tari kreatif dan mengikuti model pembelajaran konvensional menggunakan metode demonstrasi diperoleh hasil penguasaan yang berbeda. Adanya perbedaan yang signifkan hasil kemampuan motorik kasar anak antara anak yang mendapatkan perlakuan model pembelajaran tari kreatif dengan anak yang mendapatkan model pembelajaran konvensional disebabkan dengan adanya perlakuan yang berbeda dalam kegiatan pembelajaran dan proses penyampaian materi.

Secara teoritik melalui kegiatan menari anak-anak mendapatkan kesempatan dalam mengembangkan aspek perkembangan, aspek kognitif, aspek sosial emosional dan juga motorik kasar anak. Hasil penelitian ini sejalan dengan penelitian sebelumnya yang dilakukan oleh Indrawati (2012) penelitian yang berjudul " Peningkatan Kemampuan Motorik Kasar Anak Melalui Tari Kreasi Di Taman Kanak-Kanak Melati Kabupaten Solok Selatan”. Menyimpulkan pelaksanaan kegiatan 
tari kreasi yang sudah terapkan dapat meningkatkan kemampuan motorik kasar anak terhadap kemampuan anak untuk mengelola dan mengontrol koordinasi keseimbangan gerak tubuh, mengenalkan dan melatih gerak dasar serta meningkatkan keterampilan tubuh sehat sehingga dapat menunjang kemampuan jasmani yang sehat, kuat dan terampil.

Respondens dalam penelitian ini adalah anak-anak di Taman Kanak-kanak Sinar Harapan Kaliasem dan Widya kumara Sari Dencarik. Jumlah anak yang dilibatkan dalam penelitian ini adalah sebanyak 51 anak yang dibagi menjadi 2 kelompok. Kelompok eksperimen berjumlah 26 anak, kelompok kontrol berjumlah 25 anak. Kelompok eksperimen diterapkan pada Taman Kanak-kanak Sinar Harapan yang diberikan perlakuan berupa model pembelajaran tari kreatif, sedangkan kelompok kontrol diterapkan pada Taman Kanak-kanak Widya Kumara Sari yang diberikan dengan model pembelajaran konvensional. Objek pada penelitian ini adalah kemampuan motorik kasar pada anak kelompok B.

Instrumen yang digunakan untuk mengumpulkan data adalah non tes yaitu lembar observasi (rubrik penilaian). Rancangan penelitian yang digunakan dalam penelitian ini adalah racangan Nonequivalent Postest Only Control Grup Design dengan menggunakan uji-t sebagai alat untuk menganalisis data. Deskripsi data hasil perkembangan kemampuan motorik kasar yang dipaparkan meliputi nilai rata-rata,varian,standar deviasi,modus dan median. Kelompok B2 TK Sinar Harapan Kecamatan Banjar ditetapkan sebagai kelompok eksperimen yang diberi perlakuan berupa model pembelajaran tari kreatif sebanyak 6 kali perlakuan, kemudian diberikan post test untuk memperoleh hasil perkembangan kemampuan motorik kasar anak. Kelompok B TK Widya Kumara Sari Kecamatan Banjar sebagai kelompok kontrol yang diberi perlakuan berupa model pembelajaran konvensional sebanyak 6 kali pertemuan, kemudian diberikan post test untuk memperoleh hasil perkembangan kemampuan motorik kasar anak.

Deskripsi data nilai akhir hasil kegiatan motorik kasar yang memaparkan rata rata,median,modus,varians, standar deviasi,nilai minimum,nilai maksimum dan rentangan nilai dikerjakan secara manual. Data hasil Post-Test kemampuan motorik kasar pada 26 orang anak di kelompok eksperimen menunjukkan bahwa skor tertinggi adalah 84 dan skor terendah adalah 67. Diketahui bahwa rata-rata (mean) kemampuan motorik kasar anak adalah 74,84 dengan modus (Mo) 76 dan median (Me) 74,92. Sehingga diperoleh standar deviasi(SD) sebesar 3,99. Ringkasan hasil perhitungan statistik deskriptif post-test kemampuan motorik kasar anak kelompok eksperimen dapat dilihat dalam tabel 0.2. sebagai berikut.

Tabel 0.2 .

Ringkasan \begin{tabular}{lc} 
Data Kemampuan Motorik Kasar Anak Kelompok Eksperimen(post-test) \\
\cline { 2 - 2 } \multicolumn{1}{c}{ Data } & Motorik Kasar \\
\hline Statistik & Kelompok Eksperimen \\
\hline Skor Maksimal & 84 \\
\hline Skor Minimal & 67 \\
\hline Rentang & 18 \\
\hline Banyak Kelas Interval & 6 \\
\hline Panjang Kelas Interval & 3 \\
\hline Jumlah Siswa & 26 \\
\hline Mean & 74,84 \\
\hline Median & 74,92 \\
\hline Modus & 76 \\
\hline Standar Deviasi & 3,99 \\
\hline Varians & 15,92 \\
\hline
\end{tabular}

Berdasarkan perhitungan,rata-rata (mean) kelompok eksperimen adalah 74,84 dan standar deviasi adalah 3,99. Untuk mengetahui tinggi rendahnya hasil kemampuan motorik kasar anak kelompok eksperimen digunakan kriteria penilaian pada skala lima yang disusun berdasarkan kurva 
juling negatif. Perhitungan tabel skala lima dengan skor ideal adalah 84 dan skor minimal ideal adalah 21.

Berdasarkan analisis data yang telah dilakukan, diperoleh nilai rata-rata kemampuan motorik kasar anak dengan menerapkan model pembelajaran tari keatif adalah yang berada pada rentang skor 63,75 - $-79,5$ yang termasuk dalam kategori Sangat Baik/Sangat Tinggi.

Data hasil Post-Test kemampuan motorik kasar pada 25 orang anak di kelompok kontrol menunjukkan bahwa skor tertinggi adalah 55 dan skor terendah adalah 38. diketahui bahwa ratarata (mean) kemampuan motorik kasar anak adalah 45,16 dengan modus (Mo) 43,09 dan median (Me) 44,05. Sehingga diperoleh standar deviasi(SD) sebesar 4,68. Ringkasan hasil perhitungan statistik deskriptif post-test kemampuan motorik kasar anak kelompok kontrol dapat dilihat dalam tabel 0.3. sebagai berikut.

Tabel 0.3.

Ringkasan Data Kemampuan Motorik Kasar Anak Kelompok Kontrol (post-test)

\begin{tabular}{lc}
\hline Data Statistik & Motorik Kasar \\
\cline { 2 - 2 } Skor Maksimal & Kelompok Kontrol \\
\hline Skor Minimal & 38 \\
\hline Rentang & 18 \\
\hline Banyak Kelas Interval & 6 \\
\hline Panjang Kelas Interval & 3 \\
\hline Jumlah Siswa & 25 \\
\hline Mean & 45,16 \\
\hline Median & 44,05 \\
\hline Modus & 43,09 \\
\hline Standar Deviasi & 4,68 \\
\hline Varians & 21,90
\end{tabular}

Berdasarkan perhitungan,rata-rata (mean) kelompok kontrol adalah 45,16 dan standar deviasi adalah 4,68. Untuk mengetahui tinggi rendahnya hasil kemampuan motorik kasar anak kelompok kontrol digunakan kriteria penilaian pada skala lima yang disusun berdasarkan kurva juling positif. Perhitungan tabel skala lima dengan skor ideal adalah 84 dan skor minimal ideal adalah 21. Berdasarkan analisis data yang telah dilakukan, diperoleh nilai rata-rata kemampuan motorik kasar anak dengan menerapkan model pembelajaran konvensional adalah yang berada pada rentang skor $42,75-<53,25$ yang termasuk dalam kategori Cukup/Sedang.

Sebelum dilakukan pengujian hipotesis dengan analisis uji-t, terlebih dahulu harus dilakukan uji prasyarat yang meliputi uji normalitas sebaran data dan uji homogenitas varian hasil kemampuan motorik kasar anak.

Uji normalitas sebaran data dilakukan untuk membuktikan bahwa data hasil penelitian benarbenar berdistribusi normal. Uji normalitas sebaran data dilakukan terhadap hasil post-test pada kelompok eksperimen dan kelompok kontrol. Perhitungan uji normalitas pada penelitian ini menggunakan uji normalitas data chi kuadrati $(\mathrm{x} 2)$ dengan kriteria pada taraf signifikan $5 \%$ data terdistribusi normal jika X2hitung $<$ X2tabel dan derajat kebebasan ( $\mathrm{dk}=$ jumlah kelas dikurangi parameter dikurangi 1). 
Tabel 0.4.

Uji Normalitas Sebaran Data Kelompok Eksperimen

\begin{tabular}{cccccc}
\hline Rentangan & $\mathbf{f h} \%$ & Fo & fo - fh & $\begin{array}{c}(\mathbf{f o}- \\
\text { fh })^{\mathbf{2}}\end{array}$ & $\frac{(f o-f h)^{\mathbf{2}}}{\boldsymbol{f h}}$ \\
\hline $\mathbf{6 3}-\mathbf{6 7}$ & 0,59 & 1 & 0,41 & 0,16 & 0,27 \\
\hline $\mathbf{6 8}-\mathbf{7 1}$ & 3,53 & 5 & 1,47 & 2,16 & 0,61 \\
\hline $\mathbf{7 2}-\mathbf{7 5}$ & 8,87 & 7 & $-1,87$ & 3,49 & 0,39 \\
\hline $\mathbf{7 6}-\mathbf{7 9}$ & 8,87 & 10 & 1,13 & 1,27 & 0,14 \\
\hline $\mathbf{8 0}-\mathbf{8 3}$ & 3,53 & 2 & $-1,53$ & 2,34 & 0,66 \\
\hline $\mathbf{8 4}-\mathbf{8 7}$ & 0,59 & 1 & 0,41 & 0,16 & 0,27 \\
\hline Jumlah & & $\mathbf{2 6}$ & & & $\mathbf{2 , 3 4}$ \\
\hline
\end{tabular}

Hasil perhitungan uji normalitas sebaran data menggunakan statistik chi kuadrati (x2) pada kelompok eksperimen .Berdasarkan tabel Chi-square pada taraf signifikansi dengan dk=jumlah baris-1=6-1=5, didapatkan harga Chi-square tabel sebesar 11,07 dan Chi-square hitung sebesar 2,34 sehingga dapat disimpulkan bahwa $X^{\wedge} 2$ hitung $(2,34)<X^{\wedge} 2$ tabel $(11,07)$. Karena harga Chisquare hasil penelitian lebih kecil dari pada Chi-square tabel, maka dapat disimpulkan bahwa data hasil penelitian tersebut berdistribusi normal.

Tabel 0.5 .

Uji Normalitas Sebaran Data Kelompok Kontrol

\begin{tabular}{cccccc} 
Rentangan & fh\% & fo & fo - fh & $\begin{array}{c}\text { (fo- } \\
\text { fh })^{2}\end{array}$ & $\frac{(f o-f h)^{2}}{f h}$ \\
\hline $30-35$ & 0,57 & 0 & $-0,57$ & 0,32 & 0,56 \\
$36-40$ & 3,39 & 4 & 0,61 & 0,37 & 0,11 \\
$41-45$ & 8,53 & 11 & 2,47 & 6,10 & 0,71 \\
$46-50$ & 8,53 & 6 & $-2,53$ & 6,40 & 0,75 \\
$51-55$ & 3,39 & 4 & 0,61 & 0,37 & 0,11 \\
$56-60$ & 0,57 & 0 & $-0,57$ & 0,32 & 0,56 \\
Jumlah & & $\mathbf{2 5}$ & & & $\mathbf{2 , 8 0}$ \\
\hline
\end{tabular}

Hasil perhitungan uji normalitas sebaran data menggunakan statistik chi kuadrati (x2) pada kelompok kontrol. Berdasarkan tabel Chi-square pada taraf signifikansi dengan dk=jumlah baris$1=6-1=5$, didapatkan harga Chi-square tabel sebesar 11,07 dan Chi-square hitung sebesar 2,80 sehingga dapat disimpulkan bahwa $X^{\wedge} 2$ hitung $(2,80)<X^{\wedge} 2$ tabel $(11,07)$. Karena harga Chi-square hasil penelitian lebih kecil dari pada Chi-square tabel, maka dapat disimpulkan bahwa data hasil penelitian tersebut berdistribusi normal.

Tabel 0.6.

Hasil Uji Homogenitas Varians

\begin{tabular}{lccc}
\hline \multicolumn{1}{c}{$\begin{array}{c}\text { Sumber } \\
\text { Data }\end{array}$} & $\mathbf{F}_{\text {hitung }}$ & $\begin{array}{c}\mathbf{F}_{\text {tabel }} \text { dengan } \\
\text { taraf signifikan } \\
\mathbf{5 \%}\end{array}$ & Status \\
\hline $\begin{array}{l}\text { Post-test } \\
\text { kelompok }\end{array}$ & 1,37 & 4,04 & Homogen \\
eksperimen & & & \\
dan & & & \\
kelompok & & & \\
control & & & \\
\hline
\end{tabular}

Hasil uji homogenitas varians antara kelompok eksperimen dan kelompok control. Berdasarkan analisis di atas, didapatkan harga $\mathrm{F}$ hitung sebesar 1,37 . Selanjutnya harga $\mathrm{F}$ hitung dibandingkan dengan $\mathrm{F}$ tabel pada taraf signifikansi $5 \%$. Berdasarkan $\mathrm{F}$ tabel pada taraf signifikansi $5 \%$ dengan df1 $=\mathrm{k}-1=2-1=1$, dan df2 $=\mathrm{n}-\mathrm{k}=51-2=49$, didapatkan harga $\mathrm{F}$ tabel sebesar 
4,04. Hasil tersebut menunjukan $F$ hitung $(1,37)<F$ tabel $(4,04)$, sehingga dapat disimpulkan bahwa kedua kelompok data homogeny.

Berdasarkan hasil uji prasyarat, yaitu uji normalitas dan uji homogenitas varians dapat disimpulkan bahwa dari semua kelompok berdistribusi normal dan homogen. Oleh karena itu, uji hipotesis dengan uji-t dapat dilanjutkan. Berdasarkan uji prasyarat yang dilakukan yaitu uji normalitas dan uji homogenitas, diperoleh bahwa data hasil kemampuan motorik kasar kelompok eksperimen dan kelompok kontrol adalah normal dan homogen. Karna jumlah kelompok eksperimen dan kelompok kontrol tidak sama $(n 1 \neq n 2)$ dan variansnya homogen maka uji-t menggunakan rumus polled varians (sampel tidak berkolerasi).

Hipotesis yang diajukan yaitu sebagai berikut terdapat perbedaan yang signifikan terhadap kemampuan motorik kasar antara kelompok anak yang dibelajarkan Model Pembelajaran Tari Kreatif dengan anak yang di belajarkan menggunakan Model Pembelajaran Konvensional pada Kelompok B Di Taman Kanak-kanak Gugus I Kecamatan Banjar Tahun Pelajaran 2018/2019. Untuk pengujian hipotesis penelitian dijabarkan menjadi hipotesis nol $(\mathrm{H} 0)$ melawan hipotesis alternatif $(\mathrm{H} 1)$.

Tabel 0.7 .

Rangkuman Hasil Uji-T Post-Test Kelompok Ekperimen Dan Kelompok Kontrol Kemampuan Motorik Kasar

\begin{tabular}{ccccccccc}
\hline No & $\begin{array}{c}\text { Kelo } \\
\text { mpo } \\
\mathbf{k}\end{array}$ & $\mathbf{N}$ & $\begin{array}{c}\mathbf{d} \\
\mathbf{k}\end{array}$ & $\mathbf{M}$ & $\begin{array}{c}\text { Vari } \\
\text { ans }\end{array}$ & $\begin{array}{c}\mathbf{t}_{\text {hitu }} \\
\mathbf{n g}\end{array}$ & $\mathbf{t}_{\text {tabel }}$ & Keterangan \\
\hline $\mathbf{1}$ & $\begin{array}{c}\text { Eksp } \\
\text { erime }\end{array}$ & 26 & 4 & 74, & 15,9 & 24, & 2,00 & $\mathrm{H}_{0}$ ditolak, \\
& & 9 & 84 & 2 & 13 & 9 & $\mathrm{H}_{1}$ diterima \\
\hline
\end{tabular}

Berdasarkan analisis data di atas, didapatkan $\mathrm{t}$ hitung sebesar $24,13 \mathrm{t}$ hitung tersebut selanjutnya dibandingkan dengan $t$ tabel pada taraf signifikansi $5 \%$ dengan $d k=n \_1+n \_2-2=26+25$ $2=49$ adalah sebesar 2,009. Hasil tersebut menunjukan bahwa $t$ hitung $(24,13)>t$ tabel $(2,009)$, sehingga $\mathrm{HO}$ ditolak dan $\mathrm{H} 1$ diterima. Ini berarti terdapat perbedaan yang signifikan terhadap kemampuan motorik kasar antara kelompok anak yang dibelajarkan Model Pembelajaran Tari Kreatif dengan anak yang di belajarkan menggunakan Model Pembelajaran Konvensional pada Kelompok B Di Taman Kanak-kanak Gugus I Kecamatan Banjar Tahun Pelajaran 2018/2019.

\section{PENUTUP}

Berdasarkan hasil penelitian dan pembahasan diatas, dapat disimpulkan bahwa terdapat perbedaan yang signifikan hasil kemampuan motorik kasar antara anak yang mengikuti kegiatan pembelajaran tari kreatif dengan anak yang tidak mendapatkan kegiatan pembelajaran tari kreatif pada anak kelompok B di Taman Kanak-kanak Gugus I Kecamatan Banjar Tahun Pelajaran 2018/2019. Hal ini dapat dibuktikan dengan hasil kemampuan motorik kasar pada anak kelompok eksperimen dan kelompok kontrol.

Hasil analisis menunjukkan bahwa thitung $=24,13$ dengan ttabel $=2,009$ hal ini berarti nilai thitung > ttabel. Skor rata-rata kemampuan motorik kasar pada anak yang dibelajarkan dengan model pembelajaran tari kreatif (kelompok eksperimen) adalah 74,84 berada pada katagori tinggi sedangkan skor rata-rata hasil kemampuan motorik kasar pada anak yang dibelajarkan dengan model pembelajaran konvensional (kelompok kontrol) adalah 45,16 berada pada katagori cukup/sedang.

Jadi dapat disimpulkan bahwa terdapat perbedaan yang signifikan terhadap kemampuan motorik kasar antara kelompok anak yang dibelajarkan Model Pembelajaran Tari Kreatif dengan anak yang di belajarkan menggunakan Model Pembelajaran Konvensional pada Kelompok B Di Taman Kanak-kanak Gugus I Kecamatan Banjar Tahun Pelajaran 2018/2019. 


\section{DAFTAR PUSTAKA}

Agung, A.A. Gede. 2014. Metodologi Penelitian Pendidikan. Singaraja: Aditya Media Publishing.

Antara, Putu Aditya, 2015. "Pengembangan Bakat Seni Anak Pada Taman Kanak-Kanak". Volume 10. No. 1 Tahun 2015. (diunduh pada tanggal 08 Mei 2019).Tersedia pada http://journal.unj.ac.id/unj/index.php/jiv/article/view/3740

Dewi. 2013"Meningkatkan Hasil Belajar Menari Kreatif Melalui Pendekatan Pembelajaran Piaget dan Vygotsky". Jurnal Seni dan Budaya Panggung.Vol.23,No 1 (di unduh 08 Mei 2019) Tersedia pada http://id.portalgaruda.org/?ref=browse\&mod=viewarticle\&article=506134

Gunarsa, D. Singgih. 2012. Dasar dan Teori Perkembangan Anak. Jakarta: PT BPK Gunung Mulia.

Kusumastuti, Eny. 2017. Proses Pembelajaran Gerak dan lagu Yang Kreatif Berdasarkan Kurikulum 2013 Di TK Miryam Semarang “. Jurnal Seni Tari. ( di unduh pada 20 februari 2019) Tersedia pada https://journal.unnes.ac.id/sju/index.php/jst/article/view/17446

Koyan, I.Wayan. 2012. Statistik Pendidikan Teknik Analisis Data. Universitas Pendidikan Ganesha.

Peraturan Menteri Pendidikan Nasional No 137 Tahun 2014. Standar Pendidikan Anak usia Dini.Dikti: Jakarta.

Riyadi,Agus. 2008" Model Pembelajaran Tari Kreatif Untuk Meningkatkan Percaya Diri Anak Usia Taman Kanak-kanak". Jurnal Pendidikan Anak Usia Dini, Vol.2,No 1.( di unduh 08 Mei 2019). Tersedia pada https://ejournal.unisba.ac.id/index.php/golden age/article/view/3864

Samsudin. 2008. Pembelajaran Motorik di Taman Kanak-Kanak. Jakarta: Litera Predana Media Group.

Setiawan. 2014."Strategi Pembelajaran Tari anak Usia Dini". Jurnal Pedagogi, Vol 1 No 1, Agustus 2014( di unduh 16 maret 2019) Tersedia pada http://journal.umsurabaya.ac.id/index.php/Pedagogi/article/view/17

Setyosari, Punaji. 2016. Metodologi Penelitian Pendidikan dan Pengembangan. Jakarta: Kencana.

Sugiyono. 2014. Metode Penelitian Kuantitatif Kualitatif Dan R\&D. Bandung:Alfabeta,Cv.

Sukardi. 2003. Metodologi Penelitian Pendidikan. Jakarta: Bumi Aksara.

Yulianti, Ratna. 2016" Pembelajaran Tari Kreatif Untuk Meningkatkan Pemahaman Cinta Lingkungan Pada Anak Usia Dini” Jurnal Pendidikan Dan Kajian Seni. Volume.1.No:1. ( di $\begin{array}{lllll}\text { unduh } & \text { pada } 2019) . & \text { Tersedia }\end{array}$ padahttp://jurnal.untirta.ac.id/index.php/JPKS/article/view/851 